\title{
Linguistic Realizations of the Concept of FEAR
}

\author{
Liane Ströbel
}

\begin{abstract}
There is something about fear... This paper is an attempt to look into patterns of use and variation concerning the conceptualization of 'fear.' Analyzing the semantic field and syntactic structure of fear expressions in French, the following questions will be tackled: Which of the parameters associated with fear play a role in the linguistic encoding? Are there conceptual differences between the different realizations of this complex concept? Is it possible that 'fear' only has one central core or source? And finally, can members of the semantic field of fear function as a conceptual source themselves?
\end{abstract}

\section{Introduction $^{1}$}

'Fear' is an emotional response to threats and danger and one of our most important survival mechanisms. Fear can be conditioned, based on experience, gender specific, real or imaginary. Fear can be regarded as a characteristic of a person (trait anxiety) or a reaction to the loss of control in a specific situation (state anxiety). In the latter case, the experience of fear involves two cognitive processes and is followed by an adequate reaction to the situation. The first stage (Stage 1) is marked by a primary appraisal of a negative, dangerous or even life-threatening situation (involving physical or mental pain). This stage is followed by a secondary appraisal of the resources needed in order to react to the situation (Stage

1 The research presented in this paper was supported by the Collaborative Research Center 991, funded by the German Research Foundation (DFG). 
2). Finally, Stage 3 presents an adequate response to this danger (Faust 1986, Fries 2000, Boerner 2003, Bandelow 2003, 2004).

While the last two stages hardly help to enlighten the concept of fear, Stage 1 represents a productive analyzing ground in order to illustrate the complexity of the semantic field of 'fear' in French. In this stage, the sensation of fear and its dimensions (life-threatening, individual, etc.) must be defined. This cognitive process will have a great impact on the linguistic realizations (see Sections 2 to 4). In the following, an overview about the complexity of the concept of fear and the different resulting linguistic encodings will be displayed. The semantic core of fear will be redefined by analyzing the distinct semes of the nominal representations of fear (see Section 2) and certain salient conceptual sources of prototypical fear metaphors and metonymies (see Section 3).

Furthermore, in Section 4, a hypothesis for the predominance of analytic constructions (and support verb constructions in particular) will be presented. Finally, it will be demonstrated that the parameters at work, in order to classify the different degrees of the fear experience, and the semantic core inherent to all fear expressions, also have an impact on further linguistic developments and even lead to the fact that formerly negatively marked lexemes from this domain can turn - via their function as intensifiers - into positive markers (see Section 5).

\section{The parameters of the fear experience}

Fear is a primary universal emotion; therefore it comes as no surprise that the semantic field of 'fear' in French is very complex and broad. The single entities of this complex semantic field can be regarded as different stages of an emotional process (Shah 1993: $321 \mathrm{f}$.). At the same time, the entities themselves can be composed of various different sensations, ranging from excitement to nervousness. Therefore, from a semantic perspective, there does not seem to be a clear-cut delineation between the single members of this particular semantic field, but rather a spectrum of fixed parameters with potential contextual overlaps, variations and interpretations.

Before looking at the parameters, it is important to separate the semantic core of fear, which exists independently from its contextual readings. Wierzbicka (1972:59-63) defines emotions as 'shorthand abbreviations for complex expressions, i. e., descriptions of some kind'. The semantic primitives for 'fear' could 
therefore be subsumed as: 'bad, do, happen, know' (Wierzbicka 1972: 59-63). In other words, the semantic field of 'fear' consists of a conglomeration of short forms expressing - in different degrees and depending on the context - the belief that something bad and unavoidable is very likely to occur in the near future. Interestingly, the degree or intensity of this 'bad event coming towards somebody' does not seem to be anchored in the core meaning. In contrast to this definition, the current paper will illustrate that it is the intensity of the experience which plays a role in the rise of new (grammatical and lexical) linguistic functions of these fear expressions.

In the following, the continuum of the prototypical linguistic realizations of 'fear,' will be analyzed without including specific fears, such as French trac 'stage fright' or diatopic, diastratic or diaphasic varieties. The nominal fear examples cited in this section also have (causative or non-causative) adjectival counterparts (for a detailed analysis see Masseron 2008). Semantic changes of the adjectival counterparts will be illustrated in Section 5 .

The existence of adverbial counterparts with the suffix -ment (indicating the state of the subject while fulfilling an action, e. g., peureusement 'fearfully'), and the preposition 'with' (focusing on the experience the subject is exposed to in a given situation, e.g., avec angoisse [lit. 'with anguish']) will be analyzed in terms of the coexistence of synthetic and analytic constructions (Section 4) and their semantic divergences, e. g., avec horreur 'with horror' vs. horriblement 'horribly/tremendously' (Section 5).

The different parameters, such as degree in relevance, intensity, duration, appearance, control level and extension, will be illustrated with the help of dichotomies such as: strong vs. weak, permanent vs. non-permanent, sudden vs. (more or less) expected, loss of control vs. control, real vs. imaginary, and individual vs. non-individual, whereby: STRONG, PERMANENT, SUDDEN, CONTROL, REAL, and INDIVIDUAL serve as indications.

The definitions in this Section are derived from examples from Frantext (FT), Dubois, Dubois-Charlier (DDC), Trésor de la langue française (TLF) and related analyses of the semantic field of fear (Cislaru 2009, Fersenmeier 2010) and international classification schemata (Dilling, Mombour, Schmidt, \& Schulte-Markwort 2004, Krohne 2010, Rupprecht \& Moeller 2004).

As already mentioned, fear can be regarded as a characteristic of a person (trait anxiety) or a reaction to the loss of control in a specific situation (state anxiety). 
Certain fear terms can be associated with negative and permanent traits or characteristics of a person and are therefore regarded as 'fear disorders.' Others refer more to a specific situation without necessarily influencing the mental health of a person on a permanent basis.

The most general widespread term in order to express the feeling of fear in French is peur [+ STRONG, +/- PERMANENT+, +/- SUDDEN, +/- REAL, +/- INDIVIDUAL].

In contrast to Spanish miedo or Portuguese medo (both outer Romance Languages), which are derived from Latin metus 'fear', French peur and its Italian counterpart paura (both central Romance Languages) are both derived from Latin pavor 'fright.' Another nominal representation, the Latin term timor, which originally signified the fear of God and is only preserved in Spanish to express a fear based on an experience (Spanish sin temor de exagerar 'without fear of exaggeration'), did not survive in French. Nevertheless, traces of this concept can be found in French timide. In French the feeling of preoccupation, worry or concerns is expressed through crainte 'worry' or craindre 'to worry' (see Section 4), which are derived from Latin tremere (> cremere) 'to shiver.' In the construction de/par crainte/peur que/de 'worrying/fearing that,' in particular, both nouns, crainte and peur, appear synonymous (Fersenmeier 2010).

While the term peur is generally used to describe the reaction of avoiding or anticipating a certain dangerous situation, the alternative term anxiété can be regarded as a response to a higher stress level due to an accumulation of repetitive and unprocessed fears (Hock, Kohlmann 2009, Ohman 2000). The use of the term anxiété underlines an inability to adequately react [- CONTROL, + INDIVIDUAL] to a particular situation (state anxiety) or indicates a permanent and/or repetitive inability [+/- PERMANENT, -/+ SUDDEN] faced with a specific situation or problem (trait anxiety). In the latter case, it can already be regarded as a disorder and linked to the physiological state of a person.

The word panique (derived from the god Pan, who took pleasure in suddenly appearing and frightening wanderers) focuses on the individual loss of control in a given situation [- CONTROL, + INDIVIDUAL] and subsumes a sudden, frantic and often groundless or at least not (always) life threatening fear [+ STRONG, + SUDDEN, -/+ REAL].

The major difference to phobie is the appearance and duration of the suffering. Phobie originally expressed the fear of an immediate danger (state anxiety), but 
over time started expressing a trait anxiety [- SUDDEN, + PERMANENT] and can therefore be regarded as a chronic version of panique [- PERMANENT]. Besides the prototypical phobias such as acrophobia, there also exist a great number of peripheral phobias, such as bibliophobia (fear of books), cynosiophobia (fear of knowledge), and caligynophobia (fear of beautiful women). In general, this lexeme is associated with a disproportional reaction to a potential or only imaginary danger [- REAL].

State anxieties, such as those described by the French word terreur, can be regarded as a 'short term abbreviation' for an intense, sudden and overpowering fear [+ STRONG, + SUDDEN, - CONTROL], which can be either individual or also underline that this negative feeling is forced upon a community [+/- INDIVIDUAL]. The latter reading, is often linked to historic events [+ REAL], such as in the la régime de la terreur 'the reign of terror'. It shares its key features [+ STRONG, + SUDDEN, - CONTROL] with horreur, but differs from the latter in respect to its peripheral features [-/+ REAL, + INDIVIDUAL]. Horreur can therefore be described as a sudden combination of real or imaginary fear or aversion.

The feelings aroused by the first realization of a potential danger can be expressed in French through frayeur and effroi. Both denote a sudden change of something and refer to a strong, sudden, momentary and individual experience [+ STRONG, + SUDDEN, - PERMANENT, + INDIVIDUAL].

The term appréhension is associated with a negative feeling of not being prepared enough for a specific future event, e. g., exam or speaking in public [+ REAL, + STRONG, - PERMANENT, - SUDDEN, + CONTROL, + INDIVIDUAL].

The term angoisse can, like anxiété, be regarded as a vague unpleasant emotional state and can be used to underline an inability to adequately react to a given situation [- CONTROL]. In contrast to anxiété, the focus of angoisse, is more on a specific event or situation [- PERMANENT, - SUDDEN], and most of the time is accompanied by a feeling of restraint. Etymologically, both can be traced back to Proto-Indo-European *angh- 'painful, tight, restraint' (Cf. Watkins 1985, Drosdowski \& Grebe 1963 or Kluge 1975). Nevertheless, the original meaning of 'tenseness, tightness,' a symptom accompanying the fear experience, appears to be more transparent in the latter.

Alongside this abundance of possibilities for expressing the sensation of fear, it is very salient that explicit fear terms are often avoided. Jacqueline de Romilly (Membre de l'Académie française) illustrates this phenomenon in her book Dans 
le jardin des mots (2007:244-247, highlighted by the author of this paper) with the help of an anecdote describing a train ride:

'J'étais dans un compartiment de chemin de fer avec un homme inconnu et nous avons été mêlés à une sorte d'aventure policière, un troisième voyageur s'étant caché dans notre compartiment. Il fut repris par la police. Et, au matin, j'avouais à mon compagnon de voyage que j'avais eu vraiment peur, À quoi il me répondit, l'air très satisfait, « non, non, je n'ai pas eu peur: simplement, je n'étais pas rassuré ! »'

This tendency to shrink from using fear expressions might be due to the fact that they are considered too 'strong' and therefore appear inappropriate in certain situations.

To sum up, all of the fear expressions analyzed in this section share the attribute that regardless of whether the sensation of fear is real (due to a perceivable cause) or imaginary, short or permanent, individual or not, and independent of the degree of control [+/- REAL, +/- PERMANENT, +/- SUDDEN, +/- CONTROL, +/- INDIVIDUAL], this sensation is always experienced as a powerful feeling [+ STRONG]. Therefore the intensity [+ STRONG], the only parameter, that all fear expressions display can be regarded as the common semantic core of all fear expressions. The intensity inherent in all fear expression and its influence on the rise of new analytic constructions and as intensifier markers will be analyzed in detail in Sections 4 and 5.

Finally, it is also interesting that many fear expressions focus on the parameters REAL and INDIVIDUAL. This might be due to the fact that, at least in situ, for the one experiencing fear, the fear (whether real or imaginary) always appears true and real and primarily a threat to oneself and one's own body. This also explains why a majority of fear expressions can be traced back to bodily reactions or movements accompanying the fear experience, e. g., anxiété or angoisse [<'painful, tight, restraint'], crainte [<'to shiver'], etc. This close connection between fear expressions and embodiment will be analyzed in the following two sections.

\section{FEAR and embodiment}

Fear is not only expressed in a semantic primary form (as illustrated in Section 2) but - from a linguistic perspective - metonymic and metaphoric processes are at work to create new ways of expressing fear in language. 
Metaphor and metonymy have long been regarded by cognitive linguists (Lakoff 1987, 1993, Niemeier 1997, Schwarz-Friesel 2007, Sharifan, Dirven \& Niemeier 2008, Steen et al. 2010) as the result of conceptual mappings and as a productive source for meaning extension. In metaphor mappings - which take place between different semantic fields - the source domain is used to illicit the target domain. Metonymy mappings, in contrast, are hierarchically structured within one single domain (Koevecses \& Radden 1998).

Fear as a bodily experience starts in the brain. The amygdala, the hippocampus and the prefrontal cortex can be regarded as the key to and source of our fear experience (Ledoux 1996 or Roth 1997). From there it spreads to the whole body. The typical symptoms of fear include the widening of the eyes, the raising of the eyebrows, an either widely opened or shut and dry mouth, a feeling of breathlessness, a motionless body, a change in heartbeat, muscles shivering, etc.

All these symptoms also play a role in the linguistic realizations of fear. Their function is not only to describe the physical and emotional state of a person in a certain situation, but also to reduce the subjectivity of this emotion by attributing it linguistically to specific bodily reactions or inabilities. By doing so, different domains can be distinguished which allow a better identification of different degrees of fear.

Davitz (1969) produced a model consisting of twelve clusters (out of a corpus of 556 statements referring to 50 different emotions) and four dimensions of emotional meaning, namely activation, relatedness, hedonic tone, and competence.

Table 1: Davitz (1969) twelve clusters (slightly changed)

\begin{tabular}{|l|l|l|l|}
\hline DIMENSIONS & \multicolumn{3}{|c|}{ CLUSTERS } \\
\hline Activation & activation & hypoactivation & hyperactivation \\
\hline Relatedness & moving towards & moving away & moving against \\
\hline Hedonic tone & comfort & discomfort & tension \\
\hline Competence & enhancement & \multicolumn{2}{|c|}{$\begin{array}{r}\text { dissatisfaction and inadequacy } \\
\text { ( incompetence) }\end{array}$} \\
\hline
\end{tabular}

The twelve clusters consist of activation, hypoactivation, hyperactivation, moving towards, away and against, comfort, discomfort, tension, enhancement, dissatisfaction and incompetence. Taking this model as a base, it is possible to distinguish at least three clusters (highlighted in bold in Table 1), namely 'hyperacti- 
vation', 'tension' and 'incompetence,' which are closely related to the experience of fear.

Hyperactivation subsumes symptoms such as an increase in heart rate or lapses in heartbeat (avoir le cour qui bat très fort/la chamade/à grands coups), physical agitation, as in il tremblait de peur, or sweating (Il avait des mains moites), etc. A drop in temperature, as in des sueurs froides, and different incompetences, such as the inability to move (Il était pétrifié) or to speak (la gorge serrée), can be regrouped as signs of dissatisfaction or inadequacy.

Given the fact that fear is a very complex emotion and furthermore closely linked to neighboring emotions such as worry and concern (Gustafsson, Kronqvist, \& McEachrane 2009, see Section 3), its symptoms and therefore also its linguistic realizations can spread to other clusters (highlighted in gray in Table 1), such as 'hypoactivation' (avoir la bouche sèche), 'moving away' (la peur les poussait à fuir [Frantext, Jonquet 1993:208, 26]) and 'discomfort' (je n'étais pas rassuré, as illustrated, for example, in the anecdote in Section 2).

What the examples have in common is that they indicate fear without directly referring to it: the physiological effects and behavioral reactions of fear stand for the experienced fear and increase with the increase of this fear.

In addition to the metonymic expressions there are also a large number of metaphorical expressions used to express the feeling of fear. While in the metonymic representation the term fear is usually avoided or can be suppressed (e. g., Il était petrifié [de peur]), in the metaphoric representation fear can even be personified, e. g., la peur grandissait, la peur s'en va, etc.

In contrast to Koevecses (1990) detailed distinctions (e. g., fear as a fluid in a container, an intrusion, an opponent, a vicious enemy, a tormentor, a natural force, a superior, etc.), his classification will be simplified and divided into two categories in this paper: 'internal fear' and 'external fear.'

The advantage of this contrastive classification is, firstly, that possible overlaps between semantically neighboring subcategories such as FEAR AS AN OPPONENT, VICIOUS ENEMY, TORMENTOR or SUPERIOR, which can all be traced back to the same source domain attribute [somebody wants to harm the subject], can be neglected here. Secondly, that a higher categorization level of the underlying source domains of the fear metaphors becomes distinguishable.

As members of the first group, 'internal fear' can be regarded all metaphors based on the perception that fear is already a part of the body before even being 
confronted with a dangerous situation, such as FEAR IS A FLUID IN A CONTAINER (e. g., Il était rempli de peurs).

The second group, 'external fears,' subsumes all metaphors grounded in the assumption that fear is originally not a part of the body, but something forced upon it from the outside, such as an INTRUSION, e. g., la peur s'empare de lui.

In the latter case, there is no distinction made as to whether the cause of the fear is personified (human, animal or ghost) or perceived as an illness or a natural force (être submerge par la peur).

Both categories, internal and external fear, share the attribute that 'fear' can appear in form of a fluid in both of them, e. g., il était rempli de peurs (CONTAINER) vs. être submerge par la peur (NATURAL FORCE).

Interestingly, given the fact that the semantic field of fear shares many of the cited metonymies and metaphors with other emotions such as 'love' (le coeur qui bat la chamade), the only metonymy which can be considered as exclusive for the domain of fear, the simultaneous appearance of hot and cold temperatures (avoir des sueurs froides), a very intense sensation, can also be traced back to a fluid taking over the whole body of the experiencer (Dobrovol'skij \& Piirainen, 2005).

The fact that all fear metaphors fit either one of these two categories shows that fear is closely linked to the body. Fear is a bodily experience and this fact is also expressed linguistically with the help of the body as an anchorage point. Due to this close connection to the body, it comes as no surprise that the contrastive analysis represents little variation. The metaphoric and metonymic realizations of 'fear' seem to be very similar in French, Spanish, German and English: e. g., Spanish estar dominado/atenazado por el miedo/pánico, quedarse petrificado/clavado de miedo, ser invadido por el miedo, ser vencido por el miedo, German von Angst beherrscht sein, vor Angst wie versteinert sein (Bresson \& Dobrovol'skij 1995, Dobrovol'skij \& Piirainen 2005, Gyoeri 1998) with only slight differences or specification, such as in example 2c:

(2) (a) French

Elle tremblait comme une feuille.

(b) Spanish

Temblaba como una hoja.

'She was trembling like a leaf.' 
(c) German

Sie zitterte wie Espenlaub.

'She was trembling like an aspen leaf [lit. aspen leaves]'

Interestingly, the color spectrum differs slightly from language to language. While in English a person experiencing fear can be pale, white as a sheet, gray with fear or caught in a blue funk, or even green about the gills (similar to French pâlir or blêmir 'to become pale', être blanc/bleu de peur 'to be white/blue from fear', être/rester bleu 'to be/stay blue', devenir vert de peur/verdir de peur 'to go green with fear'), in Spanish and Italian a scared person can also turn yellow (Spanish ponerse amarillo, Italian diventare giallo 'to go yellow'). The reaction of the skin is expressed in all analyzed languages through a comparison with poultry: 'goose' in English and German (English goose bumps, goose pimples, German Gänsehaut [lit. goose skin]), 'hen' in French avoir la chair de poule and Spanish ponérsele carne de gallina [lit. to have/get hen flesh].

To sum it up, the aim of this section was not to single out as many features as possible but to show that fear is - even linguistically - a bodily experience.

As has been illustrated, the bodily reactions (including the hypothalamus and the vegetative system) activated after the first realization of a potential danger (fear as a physical emergency state), such as accelerated heartbeat, changes in blood pressure, breathing, muscle tension, sweating, constipation, faint, rubescence, etc. have all left linguistic traces.

Fear in language is either presented as a physical reaction or as a threat to the body. The metonymic processes describe the symptoms of experience of fear (direct or internal process). In other words: fear and body are one.

The metaphoric examples represent fear as something that is already a part of the body (internal fear) or added to the body (external fear): fear and body are connected.

Both strategies, metaphor and metonymy, are used to render an entity of the so-called 'invisible world,' namely 'fear,' which attacks the whole body without always being visible or detectable for an outsider or potential recipient, although more visible for the latter. A similar strategy, which has even led to lexical and grammatical changes, will be analyzed in the following section. 


\section{Fear and the discourse world}

The concept of 'fear' can be expressed with the help of nouns (Section 2), metaphors and metonymies (Section 3). This section will focus on the verbal realization of fear. In dealing with the semantic field of fear, it is very salient that the verbal counterparts seem either restricted or are absent. For example, the French terms peur 'fear', anxiété 'anxiety' and horreur 'horror' do not display verbal counterparts (e.g., in the case of French peur or horreur there only exist causative counterparts: apeurer or horrifier).

The gap in French is filled with verbs derived from different stems such as redouter or craindre. The semantic range of redouter and craindre varies, depending on the context, between 'to worry' and 'to fear.' In certain contexts, the meaning of these two verbs can even be interpreted as 'to expect,' as in examples (3a) and (3b). In combination with a negation craindre can also mean 'to like,' as in example (3c).

(3) (a) French (Manchette 1973:224 [FT])

Il a pris les choses beaucoup mieux que je ne craignais.

(b) French (Jonquet 1993:387 [FT])

Dès que j'ai appris que Kafin avait vécu ici, j’ai redouté le pire!

(c) French (DDC)

On ne craintpas un peu de cognac?

As the quote from Stendhal 'Je tremble toujours de n'avoir écrit qu'un soupir, quand je crois avoir noté une vérité' and the etymology of French craindre (<Latin tremere 'to shiver') illustrate, fear can be expressed, as already shown in Section 3, as a bodily experience:

(4) French (Jonquet 1993:81 [FT])

(a) L'humidité le fit frissonner. (...)

(b) L'homme resta encore quelques minutes posté derrière sa fenêtre (...) puis disparut. Nadia frissonna (...).

While in example (4a) the shivering is not caused by fear, in example (4b) fear is not only the source of the shivering but the experience of fear is also the intended interpretation of the verb. A similar interpretation of 'fear as the target' 
is intended in Tremblez riches votre Paris est encerclé on le brûlera (Manchette 1972:164 [FT]).

The semantic field of fear can also be combined with a number of verbs marking the aktionsart or in other words focusing on a specific phase of the experience of fear, such as the French prendre peur [lit. 'take fear'] (inchoative), perdre peur 'lose fear' (terminative) or faire peur, inspirer de la peur [lit. 'make/inspire fear'] (causative). Interestingly sentences such as je ressens de la peur 'I am feeling fear' are not used in order to express fear at the actual moment of experiencing it (Cislaru 2009).

The immediate experience of fear is not communicated synthetically but with the help of an analytic construction of a noun or adjective and a copula or empty verb (Stroebel 2010, 2011). The fear experience is expressed as 'possessing' a psychological state, e. g., Marie a peur [lit. 'Mary has fear'] 'Mary is scared' or as being in a psychological state as in French Marie est angoissée, anxieuse, effrayée 'Mary is afraid, scared.'

In English too, to fear seems to be restricted to expressing the fact that somebody is experiencing fear at the moment of speech and an analytic construction such as 'to be afraid' or 'to be scared' is preferred. One of the reasons for this might be that 'to fear' is transitive and therefore needs an object. In many fear situations, the source of the fear is not always clear; most of the time it is just a vague feeling. With an analytic construction, the reason for the experience of fear can be left open and does not have to be named. Another reason - if we compare this with other utterances lacking syntactic verbal counterparts such as 'I am hungry' - is that by using the copula or an empty verb construction the utterance not only appears more closely linked to the speaker but also the relevance of the utterance for the discourse world is explicitly underlined (Stroebel 2010).

In other words, an utterance with 'to be afraid' is not only more closely linked to the speaker, but also refers to a more immediate or tangible situation. 'To fear', in contrast to 'I am afraid,' implies a lack of knowledge and underlines the uncertainty of a future event (e. g., fear the worst vs. " Wierzbicka 1999:74). The meaning of to be afraid can also be disconnected from fear and simply be used as an intensifier, e. g., I am afraid, I cannot help you ( I really cannot help you, see Section 5), while to be scared is still clearly associated with the sensation of fear. 
The semantic field of fear shares the fact that stative constructions are used in order to express a physical sensation relevant to the actual speech act (e.g., 'have + abstract noun') with many other sensations connected to the discourse world (e.g., French J'ai faim, soif, mal à la tête [lit. 'I have hunger, thirst, (a) headache']). While the use of avoir is possible with a great number of nominal representations of fear, e.g., avoir peur, crainte, effroi, frayeur, terreur, angoisse, appréhension, couardise, frousse, trouille, panique, trac, etc., the use is restricted with other emotions such as *avoir (de la) jalousie, *avoir (du) colère, etc. This might be due to the fact, that in these cases the focus is more on the fact that the speaker is in a state of jealousy or anger (je suis jaloux, je suis en colere), than on the relevance to the discourse world. The combination with avoir can therefore be regarded as an attempt to render an 'entity of the invisible world' such as 'fear' less abstract by presenting it as an object in the possession of the speaker at the moment of speech.

The relation between fear and the body of the speaker is strengthened and the importance of the utterance for the actual situation is underlined.

While the French copula construction Il est peureux marks the trait of a person, the combination with avoir in Il a peur (lit. 'He has fear') underlines the relevance to the 'here and now' of the speech act. In these constructions, or in other words in combination with an abstract noun, avoir has lost its (original) durative or trait character (e.g., elle a des yeux bleus, une maison, etc.). As a consequence, in order to express that avoir in these examples is not related to a specific moment or situation, another linguistic element, such as 'always' has to be added, e. g., Il a toujours peur [lit. 'He has always fear']. Or vice versa, a specification, such as 'in this (particular) situation' has to be added to the copula construction in order to get rid of the durative interpretation, e. g., Il était trop peureux dans cette situation 'He was too afraid in this situation.'

In other words, the analytic or empty verb construction expresses that an individual experiences fear in the discourse world. This close connection to the present can fade with a rise in frequency of this construction. Further semantic developments will be analyzed in the following section. 


\section{Fear as source}

In Sections 2 to 4 the semantic field of 'fear' has been analyzed with a focus on the nominal, metaphoric, metonymic and predicative representations of fear. In all these cases, the aim of the linguistic encoding was to express the experience of 'fear.' 'Fear' can be seen as the target - even outside of a linguistic perspective.

This last section will focus on the opposite case: 'fear as the source.' More specifically: the source for intensity markers.

With time, the close connection between the physical reactions that result from being confronted with a potential danger can fade, but also the connection with the trigger, or, in other words, the relevance to the dangerous situation itself. As a consequence, fear expressions can also surface in utterances, such as French f'ai peur qu'il ne revienne très tard (Vian 1948:29, FT). In these examples, expressions originating in the semantic field of fear are used in order to underline an assumption or even a conviction.

In French, it is quite common to see members of the semantic field turn into intensity markers of subjective statements, e. g., ça craint! [lit. 'it fears'] 'It sucks!' or formidable (< Latin formidare 'to fear') 'great,' similar to awesome (< Old English ege 'fear' $[\mathrm{EO}])$.

In noun-adjective combinations, e.g., une peur panique, une peur terrible, it becomes clear that the adjective in the semantic field of fear is being used in order to intensify the noun from the same semantic field. The association to 'fear' can also be preserved in combination with a noun out of a different semantic field, e.g., une expérience horrible, une chaleur horrible, un effrayant genie (similar Iñesta \& Pamies 2002). In other words, even the negative meaning vanishes and the adjectives and adverbs from the semantic field of fear are used as simple intensifiers, such as c'est horriblement cher, il faisait horriblement chaud, sa lettre m'a fait terriblement plaisir, etc.

In all these examples, fear expressions are used as intensifiers. In other words, members of the semantic field of fear are used as a source in order to express 'intensity' [target]. In this particular use, fear expressions are - via semantic bleaching - deprived of their original negative connotations and even function as 'positive' markers. 


\section{References}

\section{Conclusion}

The analysis of the semantic field of fear has shown, that 'fear' - an entity of the 'invisible world' - is particularly suitable for analyzing the interaction between semantic and conceptual properties or, in other words, between the source and the target domain (Lakoff 1987, 1993).

It has been illustrated that the imagery and the meaning are closely connected. Embodiment plays a predominant role in the synthetic (e.g., nominal, adjectival and verbal realizations) and analytic (e. g., metonymic, metaphoric expressions and complex predicates) representations of this particular field. Embodiment can be regarded as a universal source domain for fear with two different ways of perception. First, fear as a part of the body independent of whether somebody is exposed to a dangerous situation or not, or secondly, as something external forced upon the body. Furthermore, the range of the linguistic encoding of fear combines two broad categories of experience, namely sensory and subjective. While the first type is related to image schemas (as presented in Sections 3 and 4), the second operates along fixed parameters (Section 2). Finally, it has been shown that 'intensity' plays an important factor not only in the experience of fear, but also in its linguistic encoding. As a consequence, negative marked expressions can not only function as a productive source for intensifiers (or quantifiers), but can also allow a positive reading in certain contexts.

\section{References}

Bandelow, B. (ed.) 2003. Angst und Panik, Ätiologie-Diagnostik-Therapie. Bremen: Uni-Med.

Bandelow, B. 2004. Das Angstbuch. 3. Aufl. Reinbek: Rowohlt.

Bergenholtz, H. 1980. Das Wortfeld „Angst”. Eine lexikographische Untersuchung mit Vorschlägen für ein großes interdisziplinäres Wörterbuch der deutschen Sprache. Stuttgart: Klett-Cotta.

Boerner, R.J. 2003. Panikattacken und Panikstörung. Checkliste für die Diagnose. In MMW. Fortschritte der Medizin, 2003, vol. 145, NS2, 9-12. München: Urban \& Vogel.

Bresson, D. \& Dobrovol'skij, D. 1995. Petite syntaxe de la "peur". Application au français et à l'allemand. Langue française 105. 107-119. 
Cislaru, G. 2009. Expression de la peur et interprétations sémantiques en contexte. In Mémoires de la Société Néophilologique, 45-57. Helsinki: Modern Language Society.

Davitz, J.R. 1969. The Language of Emotion. New York: Academic Press.

Dilling, H., Mombour, W., Schmidt, M.H. \& Schulte-Markwort, E. (eds.) 2004. Internationale Klassifikation psychischer Störungen (ICD 10 Kapitel V). Bern: Huber.

Dobrovol'skij, D. \& Piirainen, E. 2005. Figurative Language: Cross-cultural and Cross-linguistic Perspectives. Amsterdam: Elsevier.

Faust, V. (ed.) 1986. Angst, Furcht, Panik. Stuttgart: Hippokrates-Verlag.

Fersenmeier, Ludwig 2010. Synonyme: Zur Semantik der Absenz. In Grutschus, A. \& Krilles, P. (eds.), Figuren der Absenz - Figures de l'absence, 225-237. Berlin: Frank und Timme GmbH.

Fries, N. 2000. Sprache und Emotionen. Bergisch-Gladbach: BLT.

Gustafsson, Y., Kronqvist, C. \& M. McEachrane (eds.) (2009). Emotions and Understanding: Wittgensteinian Perspectives. Palgrave Macmillan.

Gyoeri, G. 1998. Cultural variation in the conceptualisation of emotions. In A. Athanasiaduo \& E. Tabakowska (eds.), Speaking of Emotions: Conceptualisation and Expression, 99-124. Berlin/New York: Mouton de Gruyter.

Hock, M. \& Kohlmann, C.-W. 2009. Angst und Furcht. In V. Brandstätter \& J. H. Otto (eds.), Handbuch der Allgemeinen Psychologie: Motivation und Emotion, 623-632. Göttingen: Hogrefe.

Iñesta, E.M. \& Pamies, A. 2002. Fraseología y metáfora: aspectos tipológicos y cognitivos. Granada: Granada Lingvistica / Método.

Koevecses, Z. 1986. Metaphors of anger, pride and love: A lexical approach to the structure of concepts. Amsterdam: J. Benjamins.

Koevecses, Z. 1990. Emotion Concepts. New York: Springer.

Koevecses, Z. 1998. Are there any emotion-specific metaphors? In A. Athanasiaduo \& E. Tabakowska (eds.), Speaking of Emotions: Conceptualisation and Expression, 127-151. Berlin/New York: Mouton de Gruyter.

Koevecses, Z. \& Radden, G. 1998. Metonymy: developing a cognitive linguistic view. In Cognitive Linguistics, 9 (1). 37-77.

Krohne, H. W. 2010. Psychologie der Angst. Ein Lehrbuch. Stuttgart: Kohlhammer. Lakoff, G. 1987. Woman, Fire, and Dangerous Things. Chicago: Chicago University Press. 


\section{References}

Lakoff, G. 1993. The contemporary theory of metaphor. In Andrew Ortony (ed.), Metaphor and Thought, 202-251. Second edition. Cambridge: Cambridge University Press.

Ledoux, J. 1996. The Emotional Brain. The Mysterious Underpinnings of Emotional Life. New York: Simon \& Schuster.

Masseron, C. 2008. Pour une topic de la peur : aspects psychologiques, sémiotiques, linguistiques. In Grossmann, F. \& Plane, S. (eds.), Les apprentissages lexicaux, Lexique et production verbale, 161-190. Villeneuve d'Ascq : Presses Universitaires du Septentrion.

Niemeier, S. 1997. The language of emotions: conceptualization, expression, and theoretical foundation. Amsterdam: Benjamins.

Ohman, A. 2000. Fear and Anxiety: Evolutionary, cognitive, and clinical perspectives. In M. Lewis \& J.M. Haviland-Jones (eds.). Handbook of emotions, 573-593. New York: The Guilford Press.

Romilly de, J. 2007. Dans le jardin des mots. Paris: Éditions de Fallois.

Roth, G. 1997. Das Gehirn und seine Wirklichkeit. Kognitive Neurobiologie und ihre philosophischen Konsequenzen. Frankfurt: Suhrkamp Verlag.

Rupprecht, R. \& Moeller, H. J. 2004. Hohes Risiko für Suizid und Substanzmissbrauch: Erkennen Sie Angstpatienten auf den ersten Blick? Diagnosis and treatment of panic disorder. In MMW. Fortschritte der Medizin, 2004, vol. 146, 42, 45-48. Munich: Urban \& Vogel.

Schwarz-Friesel, M. 2007. Sprache und Emotion. Tübingen: A. Francke.

Sharifan, F., Yu, N., Dirven, R., \& Niemeier, R. 2008. Culture, Body, and Language: Conceptualizations of Internal Body Organs across Cultures and Languages. Berlin: Mouton de Gruyter.

Shah, E. 1993. The Lucy ghosts. London: Corgi Books.

Steen, G. J., Dorst, A. G., Herrmann, J. B., Kaal, A, Krennmayr, T, \& Pasma, T. 2010. A method for linguistic metaphor identification: From MIP to MIPVU. Amsterdam/Philadelphia: John Benjamins.

Stroebel, L. 2010. Die Entstehung einer neuen Kategorie - Leerverben als paralleler Kopulastrang. Frankfurt/Main: Peter Lang.

Stroebel, L. 2011. Invisible, Visible, Grammaticalization. In Callies, M. Lohoefer, A. Keller, W. (eds.), Bi-Directionality in the Cognitive Sciences: Avenues, challenges, and limitations. 2011. viii, 211-234. Amsterdam/New York: John Benjamins. 
Wierzbicka, A. 1972. Semantic Primitives. Frankfurt/Main: Athenäum (Linguistische Forschungen 22).

Wierzbicka, A. 1991. Cross-Cultural Pragmatics. The Semantics of Human Interaction. Berlin: Mouton de Gruyter.

Wierzbicka, A. 1996. Semantics: Primes and Universals. Oxford: Oxford University Press.

Wierzbicka, A. 1999. Emotions across Languages and Cultures. New York: Cambridge University Press.

\section{Databases}

DDC: Dubois/Dubois-Charlier (http://rali.iro.umontreal.ca/Dubois/)

EO: http://www.etymonline.com

FT: Frantext (www.frantext.fr/)

Ernaux, A. (2007). L'événement. Paris: Gallimard.

Izzo, J.-C., (1996/2002). Chourmo. Paris: Gallimard.

Jonquet, T. (1993/2001). Les Orpailleurs. Paris: Gallimard.

Manchette, J.-P. (1973). Morgue pleine. Paris: Gallimard.

Manchette, J.-P. (1972/1999). Nada. Paris: Gallimard.

Perec, G. (2003). Entretiens et conférences II [1979-1981]. Paris: Joseph K.

Vian, B. (1948/1999). Le Grand sommeil [trad.]. Paris: Gallimard.

TLF: Trésor de la langue française (http://atilf.atilf.fr/tlf.htm)

\section{Author}

Liane Ströbel

Heinrich-Heine-University Düsseldorf

stroebel@phil.hhu.de 